\title{
Carcass and blood components of broiler chickens fed sorghum or millet as replacement for maize in the semi arid zone of Nigeria
}

\section{${ }^{1}$ Clement ljaduwa Medugu, ${ }^{2}$ Ibrahim Dankasa Kwari, ${ }^{2}$ Joseph Igwebuike, ${ }^{3}$ Iro Nkama, ${ }^{3}$ Ibrahim Dukku Mohammed and ${ }^{4}$ Bruce Hamaker}

\author{
${ }^{1}$ Borno State Agricultural Development Programme (BOSADP) Maiduguri \\ ${ }^{2}$ Department of Animal Science, University of Maiduguri, P.M.B. 1069, Maiduguri - Nigeria \\ ${ }^{3}$ Department of Food Science and Technology, University of Maiduguri, P.M.B. 1069, \\ Maiduguri - Nigeria \\ ${ }^{4}$ Department of Food Science, Purdue University, 1160 Food Science building West \\ Lafayette, IN 47907-1160 \\ ABSTRACT
}

\begin{abstract}
The effects of feeding broiler chickens with millet, low tannin and high tannin sorghum baseddiets compared to maize- based diet on the carcass measurements and blood constituents was investigated in the semi-arid zone of Nigeria. Two-week (14 days) old broiler chicks (Anak 2000) weighing averagely $351.7 \pm 5.67$ were randomly allotted to four experimental diets in which maize $\left(T_{1}\right)$ control, millet $\left(T_{2}\right)$, low-tannin sorghum $\left(T_{3}\right)$ and high tannin sorghum $\left(T_{4}\right)$ served as the energy sources in a randomized complete block design (RCBD). Each treatment contained 45 birds with three replicates of 15 birds each. Except for breast, full crop and abdominal fats, there were no significant $(P>0.05)$ differences among all the treatment groups for carcass and organ measurements. Packed cell volume (PCV), red blood cells (PBC) count and lymphocyte values were significantly $(P<0.05)$ higher in the maize $\left(T_{1}\right)$, millet $\left(T_{2}\right)$ and low tannin sorghum-based $\left(T_{3}\right)$ diets than the high-tannin sorghum based diet $\left(T_{4}\right)$. Mean corpuscular haemoglobin concentration $(\mathrm{MCHC})$, basophils and neutrophils values were however, inferior $(p<0.05)$ in the maize $\left(T_{1}\right)$, millet $\left(T_{2}\right)$ and low-tannin sorghum based $\left(T_{3}\right)$ diets compared to the high-tannin sorghum based $\left(T_{4}\right)$ diets. Blood protein and blood sodium were better $(P<0.05)$ in the sorghumbased diets $\left(T_{3}\right.$ and $\left.T_{4}\right)$ than those of maize and millet-based diets. This study therefore revealed that replacing maize with sorghum or millet has no adverse effects on carcass and blood constituents of broiler chickens.
\end{abstract}

Keywords: Broiler chickens, blood and carcass components, maize, millet, sorghum.

\section{INTRODUCTION}

The energy portion of poultry diets represents the largest single dietary ingredient. Maize which used to be the major source of energy in poultry diets is now very expensive due to low production in the drier areas of the tropics and the intense competition between man and livestock.

One important measure that can be taken to alleviate this situation is the use of alternative energy sources like sorghum and millet which are produced extensively in the semi-arid areas. Parthasarathy (2005) and Issa et al., (2007) reported that sorghum grains can play an important role in poultry feeds in the Sahelian countries. Other workers (Hancock 2000; Dowling et al., 2002 and Travis et al., 2006) have shown that sorghum could be a suitable feedstuff in the poultry industry. Cromwell and Coffey (1993) on the other hand exonerated millet from the antinutritional properties (Phytate and tannins) found in sorghum. NRC (1996) reported that millet has no tannin but contain $5-7 \%$ oil and higher protein and minerals than maize. The objective of this study was to evaluate the carcass characteristics and blood constituents of broiler chickens fed millet, low-tannin sorghum and high-tannin sorghum-based diets compared to maize-based diet.

\section{MATERIALS AND METHODS}

The study was conducted at the University of Maiduguri Teaching and Research Livestock Farm, Poultry Unit, Maiduguri. Maiduguri is characterized by semi-arid condition with short rainy season (3 - 4 months) and high ambient temperature.

One hundred and eighty (180) Anak-2000 day-old chicks were purchased from a reliable hatchery (ECWA) in Jos. The chicks were brooded together for two weeks after which they were randomly allotted to four treatments (diets) which were prepared for both 
the starter and finisher phases. Each treatment consists of 45 birds and three replicates of 15 birds per replicate.

The four experimental diets contained maize (control) $\left(T_{1}\right)$, millet $\left(T_{2}\right)$, low-tannin sorghum $\left(T_{3}\right)$ and hightannin sorghum $\left(T_{4}\right)$ as the main energy sources. The low-tannin and high-tannin sorghums are locally called "Chakalere" and "Jigari" respectively. The ingredient and chemical composition of the experimental diets was as reported by Medugu et al., 2009. The experimental diets and clean drinking water were supplied ad libitum and conventional management practices were strictly observed throughout the study which terminated when the birds were nine weeks of age.

At the end of the seven (7) weeks feeding trial, three birds each from the four treatment groups were randomly selected, one from each replicate for blood sample collection and subsequently carcass analysis. The birds were fasted overnight before the blood collection and slaughtered the next morning. The blood samples were collected in heparinized and non-heparinized tubes for the haematological and serum biochemical indices determination respectively. For the carcass measurements, the birds selected and starved were weighed individually before slaughter. The slaughter weight, plucked weight and dressed weight were determined. The dressing percentages were calculated and cut-up parts and organ measurements were carried out and expressed as percentages of the slaughter weights.

All data collected were subjected to analysis of variance (ANOVA) according to the complete randomized block design (Steel and Torrie, 1990) and significant differences between treatment means were separated using the Duncan's Multiple Range Test (Duncan, 1955).

\section{RESULTS AND DISCUSSION}

The crude protein and metabolizable energy values of the experimental diets as reported by Medugu et al. (2009) are adequate. The data on the carcass and organ measurements expressed as percentages of slaughter weights are presented in Table 1. Except for breast, full crop and abdominal fats, there were no significant $(P>0.05)$ differences among treatments for carcass and organ measurements. The breast and abdominal fat components of finished broilers are very important in assessing quality. Broilers with better developed breast meat are considered superior while heavy deposit of abdominal fat in finished broilers indicates poor finishing. From the result of this study, broilers fed millet-based diet seem to be better than those fed maize and sorghum-based diets although they do not show significant $(P>0.05)$ differences from those on maize and high-tannin sorghum based diets. Similarly, with respect to abdominal fat, broilers on millet-based diets have significantly $(P<0.05)$ lower abdominal fats than those on maize and high-tannin sorghumbased diets. These indicate that millet and sorghum can be well-utilized to produce broiler chickens with superior carcass quality compared to maize. The haematological components and blood biochemical indices are presented in Tables 2 and 3. The values for RBC, PCV and WBC were similar $(P>0.05)$ in maize, millet and low-tannin sorghum-based diets but inferior $(P<0.05)$ in the high-tannin sorghum diet. For haemoglobin concentration, the values were significantly $(P<0.05)$ lower for maize and high-tannin sorghum diets than the millet and low-tannin sorghum-based diets. The result for haematological parameters reveals that high-.tannin level depressed RBC, PCV and WBC in broilers. Tannins have been reported to adversely affect feed intake and feed efficiency in broiler chickens (Elkin et al., 1990; Douglas et al., 1993; Knox and McNab 1995). Similarly, Nelson et al. (1978) and Gualitieri and Rapaccini (1990) reported that tannins lower dry matter and protein digestibility. This explains the low RBC and PCV values recorded in the group on hightannin sorghum. Monocyte and lymphocyte values followed the same trend with the RBC, PCV and WBC but the reverse was the case with basophils and neutrophils. Increased neutrophil number (neutrophilia) generally indicates stress or infection and the case of this study could be associated with the depressive effect of the high tannin level in the high-tannin sorghum-based diet.

For serum biochemical indices, there were significant $(P<0.05)$ differences in the values of total protein, sodium, potassium, alkaline phosphate and bicarbonates (Table 3). Total protein and sodium values were significantly $(P<0.05)$ higher in the milletand sorghum-based diets compared to the maizebased diets and vice-versa for potassium value. Total serum protein is usually a reflection of the protein quality fed (Eggum, 1970). The higher total protein values obtained in the millet and sorghum based diets reflect the protein levels (Table 2 ) in these diets compared to the maize-based diet. Results from this study therefore reveal that maize could be completely replaced with millet or low-tannin sorghum in broiler diets without adverse effects on their carcass and blood components. 
Agric. Biol. J. N. Am., 2010, 1(3): 326-329

Table 1: Carcass and Organ measurements of broiler chickens fed millet and sorghum-based diets compared to maize - based diet.

\begin{tabular}{|c|c|c|c|c|c|}
\hline \multirow[b]{2}{*}{ Parameters } & \multicolumn{5}{|c|}{ Treatments (Diets) } \\
\hline & $\mathrm{T}_{1}$ (maize & $\mathrm{T}_{2}$ (millet) & $\begin{array}{l}\mathrm{T}_{3}(\text { low-tannin } \\
\text { sorghum) }\end{array}$ & $\begin{array}{l}\mathrm{T}_{3}(\text { high tannin } \\
\text { sorghum) }\end{array}$ & SEM \\
\hline Number of birds & 6 & 6 & 6 & 6 & - \\
\hline Mean live weight (g) & 2250.00 & 2167.67 & 2167.67 & 2000.00 & $293.52^{\mathrm{NS}}$ \\
\hline Slaughter weight (g) & 2188.33 & 2116.67 & 2116.67 & 1933.33 & $286.10^{\mathrm{NS}}$ \\
\hline Plucked weight (g) & 2121.11 & 2056.33 & 2051.24 & 1874.82 & $260.33^{\mathrm{NS}}$ \\
\hline Dressed weight $(\mathrm{g})$ & 1708.17 & 1635.53 & 1595.10 & 1470.43 & $218.72^{\text {NS }}$ \\
\hline Dressing percentage (\%) & 75.92 & 75.55 & 73.59 & 73.52 & $9.57^{\mathrm{NS}}$ \\
\hline \multicolumn{6}{|c|}{ Cut-up parts as percentage of slaughter weight (\%) } \\
\hline Head & 2.38 & 2.36 & 2.37 & 2.38 & $0.13^{\mathrm{NS}}$ \\
\hline Shanks & 3.80 & 4.15 & 3.98 & 3.00 & $0.41^{\mathrm{NS}}$ \\
\hline Neck & 5.10 & 5.12 & 4.94 & 4.96 & $0.10^{\mathrm{NS}}$ \\
\hline Wings & 8.76 & 8.99 & 9.08 & 9.45 & $0.14^{\mathrm{NS}}$ \\
\hline Thighs & 13.16 & 13.00 & 13.01 & 13.11 & $0.11^{\mathrm{NS}}$ \\
\hline Drumstick & 10.25 & 9.61 & 9.98 & 9.31 & $0.42^{\mathrm{NS}}$ \\
\hline Breast & $20.44^{\mathrm{ab}}$ & $21.67^{\mathrm{a}}$ & $19.13^{b}$ & $19.71^{\mathrm{ab}}$ & $0.73^{*}$ \\
\hline Thorax & 7.84 & 7.32 & 8.00 & 7.91 & $0.52^{\mathrm{NS}}$ \\
\hline Back & 10.13 & 10.14 & 10.04 & 9.90 & $0.08^{\mathrm{NS}}$ \\
\hline \multicolumn{6}{|c|}{ Organs weight as percentage of slaughter weight (\%) } \\
\hline Hear & 1.18 & 1.15 & 1.18 & 1.10 & $0.12^{\mathrm{NS}}$ \\
\hline Full-gizzard & 10.83 & 10.85 & 10.02 & 10.06 & $0.78^{\mathrm{NS}}$ \\
\hline Full-crop & $1.39^{d}$ & $2.97^{\mathrm{c}}$ & $7.25^{\mathrm{a}}$ & $5.06^{\mathrm{b}}$ & $0.56^{\star}$ \\
\hline Liver & 7.74 & 7.03 & 7.27 & 7.06 & $0.46^{\mathrm{NS}}$ \\
\hline Abdominal fats & $8.04^{\mathrm{a}}$ & $4.16^{\mathrm{C}}$ & $5.42^{\mathrm{bc}}$ & $6.02^{\mathrm{ab}}$ & $0.78^{*}$ \\
\hline
\end{tabular}

$\begin{array}{ll}\mathrm{a}, \mathrm{b}, \mathrm{c}= & \text { Mean within the same row bearing different superscripts differ significantly }(\mathrm{P}<0.05) \\ \mathrm{NS} & \text { Not significant }(\mathrm{P}>0.05)\end{array}$

SEM = Standard Error of Means

Table 2: Haematological components of broiler chickens fed millet and sorghum-based diets compared to maize based diet

\begin{tabular}{|c|c|c|c|c|c|}
\hline \multirow[b]{2}{*}{ Parameters } & \multicolumn{5}{|c|}{ Diets (treatments) } \\
\hline & $\mathrm{T}_{1}$ (maize & $\overline{T_{2} \text { (millet) }}$ & $\begin{array}{l}\mathrm{T}_{3}(\mathrm{low}- \\
\text { tannin } \\
\text { sorghum) }\end{array}$ & $\begin{array}{l}\mathrm{T}_{3}(\mathrm{high} \\
\text { tannin } \\
\text { sorghum) }\end{array}$ & SEM \\
\hline Red Blood cells (RBC) count $\left(\times 10^{6} / \mathrm{mm}^{3}\right)$ & $2.67^{\mathrm{a}}$ & $3.10^{\mathrm{a}}$ & $2.73^{\mathrm{a}}$ & $1.82^{\mathrm{b}}$ & $0.18^{*}$ \\
\hline Packed cell volume (PCV) (\%) & $31.67^{\mathrm{a}}$ & $30.00^{\mathrm{a}}$ & $31.33^{\mathrm{a}}$ & $20.00^{\mathrm{b}}$ & $1.31^{\star}$ \\
\hline Haemoglobin $(\mathrm{Hb})$ conc. $(\mathrm{g} / \mathrm{dl})$ & $4.77^{\mathrm{b}}$ & $6.83^{\mathrm{a}}$ & $5.90^{\mathrm{a}}$ & $4.07^{\mathrm{b}}$ & $0.52^{*}$ \\
\hline Mean Corpuscular volume (MCV) fentolitres) & 119.20 & 97.13 & 114.93 & 111.77 & $12.07^{\mathrm{NS}}$ \\
\hline $\begin{array}{l}\text { Mean Corpuscular haemoglobin (MCH) } \\
\text { (Picogram) }\end{array}$ & 18.06 & 20.93 & 21.62 & 22.76 & $2.59^{\mathrm{NS}}$ \\
\hline $\begin{array}{l}\text { Mean Corpuscular haemoglobin concentration } \\
\text { (MCHC) }(\%)\end{array}$ & $15.08^{c}$ & $22.92^{\mathrm{a}}$ & $18.85^{b}$ & $20.41^{\mathrm{a}}$ & $0.56^{*}$ \\
\hline White Blood Cells (WBC) Count $\left(\times 10^{3} / \mathrm{mm}^{3}\right)$ & $4.45^{\mathrm{ab}}$ & 5.13 & $4.65^{\mathrm{ab}}$ & $4.28^{\mathrm{b}}$ & $0.31^{*}$ \\
\hline Monocytes (\%) & $12.00^{\mathrm{a}}$ & $13.67^{\mathrm{c}}$ & $10.86^{\mathrm{a}}$ & $6.67^{c}$ & $0.60^{*}$ \\
\hline Lymphocytes (\%) & $46.00^{c}$ & $48.00^{\mathrm{a}}$ & $48.00^{\mathrm{a}}$ & $41.67^{\mathrm{b}}$ & $1.39^{\star}$ \\
\hline Basophils (\%) & $0.00^{\mathrm{b}}$ & $0.00^{\mathrm{b}}$ & $0.03^{\mathrm{b}}$ & $2.00^{\mathrm{a}}$ & 0.001 \\
\hline Neutrophils (\%) & $34.00^{\mathrm{b}}$ & $33.00^{\mathrm{b}}$ & $34.00^{\mathrm{b}}$ & $43.00^{\mathrm{a}}$ & $2.17^{\star}$ \\
\hline Eosinophils (\%) & 8.00 & 8.67 & 7.67 & 6.33 & $0.65^{\mathrm{NS}}$ \\
\hline
\end{tabular}

$\begin{array}{lll}\text { a,b,c } & = & \text { Mean within the same row bearing different superscripts differ significantly }(\mathrm{P}<0.05) \\ \mathrm{NS} & = & \text { Not significant, }\end{array}$

NS $\quad=\quad$ Not significant,

significant $(P<0.05)$ 
Agric. Biol. J. N. Am., 2010, 1(3): 326-329

Table 3: Serum biochemical indices of broiler chickens fed millet-and sorghum-based diets compared to maize-based diets

\begin{tabular}{|c|c|c|c|c|c|}
\hline \multirow[b]{2}{*}{ Parameters } & \multicolumn{5}{|c|}{ Diets (Treatments) } \\
\hline & $\mathrm{T}_{1}$ (maize & $\mathrm{T}_{2}$ (millet) & $\begin{array}{l}\mathrm{T}_{3} \text { (low-tannin } \\
\text { sorghum) }\end{array}$ & $\begin{array}{l}\mathrm{T}_{3} \text { (high } \\
\text { tannin } \\
\text { sorghum) }\end{array}$ & SEM \\
\hline Total protein (g/dl) & $16.00^{\mathrm{a}}$ & $26.00^{\mathrm{a}}$ & $34.00^{\mathrm{a}}$ & $29.00^{\mathrm{a}}$ & $3.08^{*}$ \\
\hline Albumin $(\mathrm{g} / \mathrm{dl})$ & 14.00 & 12.50 & 14.00 & 12.00 & $1.67^{\mathrm{NS}}$ \\
\hline Globulin (g/dl) & $2.00^{\mathrm{b}}$ & $15.50^{\mathrm{a}}$ & $20.00^{\mathrm{a}}$ & $16.33^{\mathrm{a}}$ & $2.70^{\star}$ \\
\hline Sodium (mmol/L) & $147.50^{\mathrm{b}}$ & $160.00^{\mathrm{a}}$ & $155.00^{\mathrm{a}}$ & $154.00^{\mathrm{a}}$ & $1.91^{\star}$ \\
\hline Potassium (mmol/L) & $5,60^{\mathrm{a}}$ & 4.60 & $4.40^{\mathrm{a}}$ & $4.50^{\mathrm{a}}$ & $0.29^{\star}$ \\
\hline Alkaline Phosphate (iu/L) & $147,00^{b}$ & $187.00^{\mathrm{a}}$ & $137.50^{\mathrm{b}}$ & $146.50^{b}$ & $12.90^{*}$ \\
\hline Bicarbonates (mmil/L) & $1650^{c}$ & $18.50^{\mathrm{a}}$ & $19.50^{+a}$ & $18.50^{\mathrm{a}}$ & $0.90^{*}$ \\
\hline Calcium (mmol/L) & 2.35 & 2.25 & 2.20 & 2.30 & $0.06^{\mathrm{NS}}$ \\
\hline Chlorides (mmol/L) & 115.00 & 120.00 & 120.00 & 120.40 & $1.98^{\mathrm{NS}}$ \\
\hline Inorganic phosphate $(\mathrm{mmol} / \mathrm{L})$ & 0.85 & 1.10 & 1.07 & 0.90 & $0.09^{\mathrm{NS}}$ \\
\hline Urea $(\mathrm{mmol} / \mathrm{L})$ & 3.45 & 3.10 & 3.10 & 3.25 & $0.28^{\mathrm{NS}}$ \\
\hline Creatine (mmol/L) & 62.00 & 61.50 & 61.50 & 61.00 & $2.07^{\mathrm{NS}}$ \\
\hline Cholesterol (mmol/L) & 3.25 & 2.85 & 2.65 & 3.65 & $0.50^{N S}$ \\
\hline
\end{tabular}

$\mathrm{a}, \mathrm{b}, \mathrm{c}=\quad$ Mean within the same row bearing different superscripts differ significantly $(\mathrm{P}<0.05)$

* $\quad=\quad$ Significant $(P<0.05)$

NS $\quad=\quad$ Not significant $(P>0.05)$

\section{ACKNOWLEDGEMENT}

Financial support in part by a grant from INTSORMIL to University of Maiduguri is gratefully acknowledged.

\section{REFERENCES}

Cromwell, G.L. and Coffey, R.B. (1993). An assessment of the availability of phosphorus in feed ingredients for nonruminants. Proceedings of the Maryland Nutrition Conference for Feed Manufacturers. pp.146-158, Maryland USA.

Douglas, J.H., Sullivan, T.W., Gonzalez, N.J. and Beck, M.M. (1993). Differential age response of Turkeys to protein and sorghum tannin levels. Poult. Sci 72:19441951

Dowling, L.F., Arndt, C and Hamaker, B.R. (2002). Economic viability of high digestibility sorghum as feed for market broilers. Agron. J. 94:1050-1058

Duncan, D.B. (1955). Multiple Range and F-Test. Biometrics. 11:1-42.

Eggum, O. (1970). The nutritional value of feedstuffs. British J. Nutr. 24:983-988.

Elkin, R.G., Roglar, J.C. and Sullivan, T.W. (1990). Comparative effects of dietary tannins in ducks, Chicks and rats. Poult. Sci 69:1685-1695.

Gualitieri, M. and Rapaccinni, S. (1990). Sorghum grains in poultry feeding. World's Poultry Sci. J 46:246-254.

Hancock, J.D. (2000). Value of sorghum and sorghum coproducts in diets for livestock In: Smith W. and R. A. Frederickson (ed.), Sorghum origin, history, Technology and Production. Willey Series Crop Sci. pp 731-751

Issa S. Hancock, J.D., Tuinstra, M.R., Kapran, I. and Kaka, S. (2007). Effects of sorghum variety on growth and carcass characteristics in broiler chicks reared in West Africa. J. Poult. Sci. 86: 69.

Knox, A.I. and McNab, J.M. (1995). Selection between high and low-tannin diets by broiler chickens. British Poult. Sci. 36: 849.

Nelson, T.S., Stephenson, E.L., Bargos, A., Floyd, J. and York, J. (1975). Effects of tannin content and dry matter digestion on energy utilization and average amino acids availability of hybrid sorghum grains. Poultry Sci. 54: 1620-1623.

NRC (1996). National Research Council. Nutrient requirement of Domestic Animals: Nutrient requirement of Poultry. $9^{\text {th }}$ ed. National Academy Press, Washington, D.C., USA

Olomu, J.M. (1995). Monogastric Animal Nutrition. Principles and Practices. A. JACHEM Publication, Benin City, Nigeria. pp 320

Parthasarathy, P.R., Guravo, K.R, Reddy, V.S. and Gowda, C.K. (2005). Linking producers and processors of sorghum for poultry feed. A case study from India. International Crops Research Institute for the Semi Arid Tropics (ICRISAT), New Delhi, India. pp 12

Pour-Reza, J. and Edriss, M.A. (1997). Effects of dietary sorghum of different tannin concentration and tallow supplementation on the performance of broiler chicks. British Poult. Sc, 38: 512.

Steel, R.G.D. and Torrie, J.H. (1980). Principles and Procedures of Statistics: A Biometrical Approach, $2^{\text {nd }}$ ed. McGraw Hill Books Co. Inc. New York. pp 63.

Travis, D.K., Tuinstro, M.R. and Hancock, J.D. (2006). Variation in nutritional value of sorghum hybrids with contrasting seed weight characteristics and comparisons with maize in broiler chicks. Crop Sci. 46: 695-699. 